\title{
Studi tentang Perilaku Perundungan Siswa Sekolah Menengah Kejuruan (SMK) di Kabupaten Bima
}

Saraswati Haylian Chiani ${ }^{1}$, Neti Sulami ${ }^{2}$, Arindiah Puspo Windari ${ }^{3}$, Bambang Irawan ${ }^{4}$, Novi Indrayani ${ }^{5}$

${ }^{1}$ Dosen STKIP Paracendekia NW Sumbawa, ${ }^{2}$ Dosen Akbid Surya Mandiri Bima, ${ }^{3}$ Dosen STIKES Maluku Husada,

${ }^{4}$ Dosen Akbid Harapan Bunda Bima, ${ }^{5}$ Dosen Universitas Respati Yogyakarta, Indonesia

E-mail: saraswatichiani@gmail.com,netisulami@gmail.com,arindiahwindari12@gmail.com, bambangirawan33@gmail.com,novi_indrayani11@gmail.com

\begin{tabular}{ll}
\hline Article Info & Abstract \\
\hline $\begin{array}{l}\text { Article History } \\
\text { Received: 2021-12-27 }\end{array}$ & $\begin{array}{l}\text { This research is a qualitative research aimed at understanding social phenomena from } \\
\text { Revised: 2022-01-22 } \\
\text { the participant's point of view, meanwhile the subjects in this study are counseling } \\
\text { guidance teachers, students related to bullying behavior in schools, teenagers (high } \\
\text { school students in grades 10,11 and 12). The locations taken in this research are } \\
\text { vocational high schools, both public and private in Bima Regency, namely SMKN } 2\end{array}$ \\
Keywords: & $\begin{array}{l}\text { Soromandi and SMK Kasman Bima, the results of this study indicate that bullying in } \\
\text { Behavior; } \\
\text { Bullying; }\end{array}$ \\
Student; & schools starts from elementary school where students who bully are also victims of \\
School. & family factors caused by a lack of parental love and lack of attention. given by parents \\
& to students because the majority of parents are farmers who are more normal and due \\
& to family factors caused by a lack of parental love and lack of attention given by parents \\
& to students because the majority of parents are farmers who spend more time in the \\
& fields and rice fields so that there is no control and guidance for children. In addition, \\
bullying by students towards other students is mostly verbal bullying, namely mocking \\
or mocking parents' names, which does not get the attention of teachers and schools \\
and schools only focus on the problem-solving stage without further assistance. against \\
students who are bullied by looking at the psychological condition of the child.
\end{tabular}

\begin{tabular}{l}
\hline Artikel Info \\
\hline Sejarah Artikel \\
Diterima: 2021-12-27 \\
Direvisi: 2022-01-22 \\
Dipublikasi: 2022-02-01
\end{tabular}

Kata kunci:

Perilaku;

Perundungan;

Siswa;

Sekolah.

\begin{abstract}
Abstrak
Penelitian ini adalah penelitian kualitatif ditujukan untuk memahami fenomenafenomena sosial dari sudut pandang partisipan sementara itu subyek dalam penelitian ini adalah guru bimbingan konseling, siswa-siswi yang terkait perihal perilaku perundungan disekolah, remaja (siswa SMA kelas 10, 11 dan 12). Lokasi yang diambil dalam penelitian ini adalah sekolah Sekolah Menengah Kejuruan baik Negeri dan Swasta di Kabupaten Bima yaitu SMKN 2 Soromandi dan SMK Kasman Bima, hasil dari penelitian ini diketahui bahwa tindakan perundungan di sekolah dimulai dari sekolah dasar dimana siswa yang melakukan perundungan merupakan korban perundungan juga sehingga hal tersebut terbawa sampai seterusnya dan dianggap hal yang normal dan dikarenakan adanya faktor keluarga yang disebabkan oleh kurangnya kasih sayang orang tua dan kurangnya perhatian yang diberikan oleh orang tua kepada siswa disebabkan mayoritas orang tua siswa adalah petani yang lebih banyak yang normal dan dikarenakan adanya faktor keluarga yang disebabkan oleh kurangnya kasih sayang orang tua dan kurangnya perhatian yang diberikan oleh orang tua kepada siswa disebabkan mayoritas orang tua siswa adalah petani yang lebih banyak menghabiskan waktu di lading dan sawah sehingga tidak ada kontrol dan bimbingan kepada anak. Selain itu, tindakan perundungan yang dilakukan siswa kepada siswa lain lebih banyak adalah perundungan secara verbal yaitu saling mengolok atau mengejek nama orang tua yang dimana hal tersebut kurang mendapatkan atensi dari pihak guru dan sekolah serta sekolah hanya fokus pada tahap penyelesaian masalah tanpa melakukan pendampingan lebih lanjut terhadap siswa yang dirundung dengan melihat kondisi psikologis anak.
\end{abstract}

\section{PENDAHULUAN}

Tindakan perundungan atau yang dikenal dengan istilah Bullying adalah tindakan atau sikap agresif yang dilakukan secara sengaja baik dilakukan oleh perseorangan maupun dilakukan oleh suatu kelompok orang secara terus menerus kepada seorang korban yang tidak mampu untuk membela dirinya sendiri (Goodwin, 2010). Menurut Republika (2016), kasus perundungan sering terjadi di lingkungan sekolah dan menjadi mata rantai yang tidak pernah terputus. Berdasarkan data yang diperoleh dari KPAI dari 
tahun 2013 sampai tahun 2016 terdapat jumlah kasus pengaduan sebanyak 369 kasus. Perundungan yang disebut KPAI lebih kepada perundungan dalam bentuk fisik yang terjadi di lingkungan sekolah. Berdasarkan Infodatin (2018) menjelaskan bahwa jenis kekerasan terhadap anak adalah kekerasan secara fisik (pukul, tampar, tendang, cubit dsb), emosional (kekerasan kata-kata yang menakut-nakuti, mengancam, menghina, mencaci dan memaki dengan kasar dan keras), seksual (pornografi, perkataan porno, tindakan tidak senonoh, pelecehan organ seksual) sehingga hal ini dapat membawa dampak tidak baik bagi si korban seperti merasa malu, minder, takut, sedih, cemas dan jika hal ini dibiarkan tanpa adanya penanganan lebih lanjut maka si korban akan mengalami depresi (Okoth, 2014). Center for Desease Control and Prevention pada tahun 2016 menyampaikan bahwa dampak dari perundungan yang dialami oleh korban jika tidak ditangani dengan segera selain korban akan mengalami depresi juga akan berujung pada kasus bunuh diri. Di Indonesia sendiri kasus perundungan masih tergolong rendah jika dibandingkan dengan negara Asia tenggara dengan presentase kasus 20,6\% dimana di negara Asia Tenggara lainnya sebanyak 36,2\% (Arafah, Amalia, Nurbaiti, Kadriyan \& Pujiarohman, 2019).

Penelitian mengenai kasus perundungan yang dilakukan oleh anak usia sekolah menengah di beberapa Negara dengan pendapatan ekonomi tinggi didapatkan angka kejadian kasus perundungan $5-57 \%$ kasus sementara itu, untuk Negara dengan pendapatan ekonomi menengah atau rendah angka kejadian kasus perundungan didapatkan lebih tinggi yaitu $12-100 \%$ kasus (Fleming dan Jacobsen, 2010). Olweus (1993) dalam Wiyani (2012) mengatakan bahwa korban perundungan lebih mempunyai kecemasan dan perasaan tidak aman yang berlebih jika dibandingkan dengan yang tidak mengalami perundungan serta korban perundungan akan lebih bersikap hati-hati kepada orang lain, namun selama ini ketika guru dan orangtua mengetahui ada peristiwa perundungan yang terjadi di sekolah mereka hanya berfokus pada perilaku yang tampak dan bagaimana untuk mengatasinya tanpa memedulikan bagaimana perasaan dan dampak psikologis yang harus diterima oleh korban perundungan setelah peristiwa tersebut. Terkait dengan data dari Dinas Pendidikan dan Kebudayaan Provinsi NTB mengenai kasus perundungan di Kota Bima tidak didapatkan dan dari pihak sekolah hanya mencatat kasus perundungan dalam bentuk fisik saja sedangkan kasus perundungan tidak hanya sekedar perundungan fisik namun juga dalam bentuk verbal, seksual dan melalui media social.

\section{METODE PENELITIAN}

Metode penelitian adalah penelitian deskriptif dimana penelitian ini berusaha untuk menggambarkan suatu gejala, peristiwa, keasian yang tejadi pada saat sekarang, penelitian kualitatif ditujukan untuk memahami fenomena-fenomena sosial dari sudut pandang partisipan, penelitian kualitatif sifatnya deskriptif analitik, data yang diperoleh seperti hasil pengamatan, hasil wawancara, hasil pemotretan, analisis dokumen, catatan lapangan, disusun peneliti dilokasi penelitian, tidak dituangkan dalam bentuk dan numerik. Hasil analisis data berupa pemaparan mengenai situasi yang diteliti yang disajikan dalam bentuk uraian naratif (Gunawan, 2013), subyek dalam penelitian ini adalah guru bimbingan konseling, siswa-siswi yang terkait perihal perilaku perundungan disekolah, remaja (siswa SMA kelas 10, 11 dan 12. Lokasi yang diambil dalam penelitian ini adalah sekolah Sekolah Menengah Kejuruan baik Negeri dan Swasta di Kabupaten Bima yaitu SMKN 2 Soromandi dan SMK Kasman Bima.

\section{HASIL DAN PEMBAHASAN}

Hasil penelitian yang telah dilakukan baik di SMKN 2 Soromandi dan SMK Kasman Bima diperoleh bahwa adanya tindakan perundungan di sekolah dengan faktor dimulainya tindakan ini saat di sekolah dasar atau awal sekolah menengah pertama yang dimulai dengan dilakukannya tindakan perundungan secara verbal yang dimana siswa saling mengolok nama orangtua masing-masing siswa. Hal ini pun diketahui oleh pihak sekolah dan guru kelas ataupun guru BK namun perilaku perundungan verbal dengan mengolok nama orangtua masih dianggap wajar dan tidak dilakukan tindakan bimbingan konseling baik terhadap siswa yang melakukan perundungan maupun siswa dirundung. Tindakan perundungan yang dilakukan sejak sekolah dasar ini sampai terbawa ketika siswa menempuh sekolah menengah atas/kejuruan menjadi budaya negatif yang tidak disadari baik oleh siswa maupun oleh guru dan sekolah. Hal ini disebabkan mindset siswa, guru dan sekolah yang masih menganggap bahwa perbuatan perbuatan perundungan hanya sebatas tindakan kekerasan fisik seperti memukul, mencubit, menampar, menendang dsb. 
Setelah dilakukan penelitian lebih mendalam kepada siswa sebagai informan penelitian bahwa kasus perundungan yang semula hanya mengolok nama orangtua oleh sebagian siswa yang tidak bisa menerima dirundung berlanjut kearah perkelahian antar siswa dan biasanya pihak sekolah dibantu oleh guru BK akan memanggil siswa yang bersangkutan dan orangtua siswa untuk dilakukan mediasi. Namun ketika dilakukan wawancara kepada pihak sekolah bahwa guru dan sekolah hanya fokus untuk mendamaikan antar siswa yang mempunyai masalah tanpa diberikan penanganan secara psikologis terutama pada anak yang dirundung, hal ini tentu saja memberikan efek yang kurang baik kepada anak yang dirundung mengingat anak yang sering dirundung akan mengalami gangguan psikologis jika tidak didampingi secara intens. Hal ini sejalan dengan pernyataan yang dikemukakan oleh Olweus (1993) dalam Wiyani (2012) mengatakan bahwa korban perundungan lebih mempunyai kecemasan dan perasaan tidak aman yang berlebih jika dibandingkan dengan yang tidak mengalami perundungan serta korban perundungan akan lebih bersikap hati-hati kepada orang lain.

Adapun jika dikaji dari faktor yang mempengaruhi tindakan perundungan ini menurut hasil penelitian yang telah dilakukan bahwa faktor yang paling banyak membuat siswa melakukan tindakan perundungan di sekolah adalah faktor dari diri pribadi siswa tersebut dan faktor keluarga, dari faktor pribadi siswa sendiri yaitu, siswa menjadi seorang pelaku perundungan dikarenakan siswa sebelumnya merupakan salah satu korban perundungan juga. Sehingga siswa tersebut mempunyai pemikiran bahwa dirinya juga berhak melakukan perundungan kepada orang lain sama dengan yang ia rasakan. (Verlinden, Herson \& Thomas, 2000), untuk faktor keluarga sendiri didapatkan hasil bahwa latar belakang keluarga yang kurang harmonis, kurangnya kasih sayang orang tua, didikan yang tidak sempurna dan kurangnya pengawasan ketika dirumah menyebabkan siswa berpotensi untuk melakukan tindakan perundungan di sekolah. Seperti yang terjadi pada siswa di SMKN 2 Soromandi menjelaskan bahwa dirinya sering ditinggal kedua orang tuanya untuk bekerja di lading dan tidak ada waktu untuk mengontrol dan memberikan bimbingan kepada anak sehingga tidak ada kontrol dari sisi orang tua kepada si anak.

\section{SIMPULAN DAN SARAN}

\section{A. Simpulan}

Berdasarkan hasil penelitian yang telah dilakukan oleh peneliti dapat disimpulkan bahwa tindakan perundungan di sekolah menengah kejuruan yang ada di Kabupaten Bima dengan mengambil 2 sampel sekolah baik negeri maupun swasta yang berada di Kecamatan Soromandi dan Kecamatan Bolo tindakan perundungan dimulai dari sekolah dasar dimana siswa yang melakukan perundungan merupakan korban perundungan juga sehingga hal tersebut terbawa sampai seterusnya dan dianggap hal yang normal dan dikarenakan adanya faktor keluarga yang disebabkan oleh kurangnya kasih sayang orang tua dan kurangnya perhatian yang diberikan oleh orang tua kepada siswa disebabkan mayoritas orang tua siswa adalah petani yang lebih banyak menghabiskan waktu di ladang dan sawah sehingga tidak ada kontrol dan bimbingan kepada anak. Selain itu tindakan perundungan yang dilakukan siswa kepada siswa lain lebih banyak adalah perundungan secara verbal yaitu saling mengolok atau mengejek nama orang tua yang dimana hal tersebut kurang mendapatkan atensi dari pihak guru dan sekolah serta sekolah hanya fokus pada tahap penyelesaian masalah tanpa melakukan pendampingan lebih lanjut terhadap siswa yang dirundung dengan melihat kondisi psikologis anak.

\section{B. Saran}

Adapun saran yang dapat disampaikan berdasarkan hasil penelitian adalah apapun tindakan perundungan wajib dilakukan sosialiasi anti perundungan disekolah dengan melibatkan semua pihak meliputi warga sekolah, orang tua, komite sekolah dan masyarakat, tanpa membedakan jenis perundungannya dan guru serta sekolah tidak boleh hanya berfokus pada tahap penyelesaian masalah saja akan tetapi memberikan layanan pendampingan kepada siswa pasca perundungan sehingga menghindarkan anak terhadap gangguan traumatik yang membuat siswa menjadi tertutup, minder, malu, stress, depresi bahkan mengarah ke jalan bunuh diri bahkan dapat membuat siswa dari yang semula adalah korban menjadi pelaku perundungan. 


\section{DAFTAR RUJUKAN}

Arafah, Amalia, Nurbaiti, Kadriyan \& Pujiarohman. 2019. Public Sharing on Prevention and Impact of Bullying in Adolescents. Prosiding PEPADU, Vol 1, 153159. Diakses tanggal 12 Januari 2022.

Fleming, L., \& Jacobsen, K. H. 2009. Bullying among middle school students in low and middle income countries. Journal Health Promotion International, 25:1, 73-82.

Goodwin, D. 2010. Strategi Mengatasi Bullying, terj. Cicilia Evi, Batu: Lexy Pello

Gunawan, I. 2013. Metode Penelitian Kualitatif: Teori dan Praktek. Jakarta : Bumi Aksara.

Infodatin. 2018. Kekerasan Terhadap Anak dan Remaja. Pusat Data dan Informasi Kementerian Kesehatan RI. Diakses tanggal 12 Januari 2022
Okoth, 0. 2014. Teachers' and Students' Perceptions on Bullying Behaviour in Public Secondary Schools in Kisumu East District, Kisumu County, Kenya. Journal of Educational and Social Research, Vol 4:6,125-138. Diakses tanggal 12 Januari 2022.

Republika. 2016. Aduan Bullying Tertinggi. https://www.republika.co.id/berita/kora n/halaman-1/14/10/15/ndh4sp-aduanbullying-tertinggi. Diakses tanggal 12 Januari 2022

Verlinden, S., Herson, M. \& Thomas, J. 2000. Risk factors in school shootings. Clinical Psychology Review. 20:3-56. Diakses tanggal 12 Januari 2022.

Wiyani, N. 2012. Save Our Children From School Bullying. Yogyakarta : Ar-Ruzz Media 